International Journal of Current Microbiology and Applied Sciences

ISSN: 2319-7706 Volume 6 Number 8 (2017) pp. 2692-2697

Journal homepage: http://www.ijcmas.com

Original Research Article

https://doi.org/10.20546/ijcmas.2017.608.322

\title{
Effect of Integrated Nutrient Management and Tree Spacing on Production Potential of Maize (Zea mays) Under Poplar Based Agroforestry System
}

\author{
Garima* and K.S. Pant
}

Department of Silviculture and Agroforestry, Dr Y S Parmar University of Horticulture and

Forestry Nauni, Solan, HP 173230, India

*Corresponding author

\section{A B S T R A C T}

Keywords

Integrated nutrient management,

Poplar, FYM, VC,

Agri-silviculture

system.

Article Info

Accepted:

23 June 2017

Available Online:

10 August 2017
The experiment was carried out at experimental farm of Department of Silviculture and Agroforestry, Dr Y S Parmar University of Horticulture and Forestry, Nauni, Solan (HP) in the year 2016. Experiment was laid out in RBD factorial design in poplar based agroforestry system with three spacing viz., $S_{1}(6 \mathrm{~m} \times 4 \mathrm{~m}), \mathrm{S}_{2}(4 \mathrm{~m} \times 4 \mathrm{~m})$ and $\mathrm{S}_{3}$ (open control without poplar trees) under which maize crop was grown and six fertilizer treatments viz., $\mathrm{T}_{1}$ (RDF), $\mathrm{T}_{2}$ (FYM on $\mathrm{N}$ equivalent ratio), $\mathrm{T}_{3}$ (VC on $\mathrm{N}$ equivalent ratio), $\mathrm{T}_{4}$ (75\% FYM and $25 \%$ Vermicompost (on $\mathrm{N}$ equivalent ratio), $\mathrm{T}_{5}\left(50 \% \mathrm{FYM}\right.$ and $50 \%$ Vermicompost (on $\mathrm{N}$ equivalent ratio) and $\mathrm{T}_{6}$ (50\% (25\%FYM + 25\% Vermicompost $)+50 \%$ chemical fertilizer $)$. Results showed that treatment $\mathrm{T}_{6}$ reported maximum plant height, cob length, 1000 grain weight, grain yield and straw yield and showed its superiority over other treatments. However, among tree spacing levels, $S_{3}$ (without trees) recorded maximum growth as compared to others.

\section{Introduction}

Poplar (Populous deltoides) is a multipurpose fast growing valuable timber species has emerged as one of the most suitable tree species for agri-silviculture system. Poplar based agroforestry systems are economically viable and more sustainable than many other crop rotations prevalent in North India (Singh and Sharma, 2006). Poplar has become the most preferred cash crop in north-western states (Chandra, 1986). The farmers grow poplar due to its short duration, ease of regeneration, easy availability of quality planting material, good market demand and its compatibility with agricultural crops.
Poplar plantations intercropped with agricultural crops have better growth than those without intercrops and the growth of trees is viable under different intercrops. Almost any crop (cereals, pulses, vegetables, forage, fruit/vegetable crops, etc.) can be grown with it (Chauhan and Mangat, 2006). The number of agricultural crops (wheat, mustard, turmeric, ginger, colocasia, cabbage, potato, spinach, garlic, etc.) including fruit crops (citrus, guava, mango, etc.) can be profitably raised with poplar (Sharma, 1996). Poplar intercropping is a highly lucrative and profitable venture, since market for its 
products are readily available because of established processing industries in the region (approximately 1,200 units of all category in Punjab, Haryana, Delhi, Uttarakhand, Uttar Pradesh, etc.). Poplar wood is used in packing cases, hard boards, veneers, sports goods, construction works and as pulp wood and poles. Besides, Indian matchwood industry uses its wood for manufacturing match splints and lops and tops as fuel wood are also not rare. These facts show that poplar wood has huge demand in wood based industries.

Further, soil fertility is decreasing day by day and area under problematic soils is increasing due to the high and injudiciously use of inorganic fertilizers. The long-term use of inorganic fertilizers without organic supplements damages the soil physical, chemical and biological properties and cause environmental pollution (Albiach et al., 2000). To reduce soil deterioration, the only possible way is integration of organic, bio and chemical fertilizers, so as to maintain crop productivity along with improvement and /or maintain soil fertility. Integrated nutrient management and agroforestry land use systems are among the best solution for the ever-escalating price and shortage of chemical fertilizers for small holder farmers, to increase soil fertility, in the developing world. Therefore, an integrated approach inorganic fertilizers, biological sources and organic manures in agroforestry systems will go a long way in building soil fertility and land productivity on a sustainable basis, since the system will supply almost all the nutrients in a judicious way, besides increasing the nutrient use efficiency and improving the soil physico-chemical properties.

Zea mayz is a grass, a member of the monocot family (Poaceae), cultivated for the edible components of its grain, composed of the endosperm, germ and bran. In their natural form, they are a rich source of vitamins, minerals, carbohydrates, fats, oils and protein. In some developing nations, grain in the form of rice, wheat, millet or maize constitutes a majority of daily sustenance. In developed nation cereal consumption is moderate and varied but still substantial. Maize (Zea mays) is one of the most versatile emerging cash crops having wider adaptability under varied climatic conditions. It is called queen of cereals globally. In India, it is the third most important cereal crop after wheat and rice which accounted 26.14 million tones production in 2016 (FAO/GIEWS, 2016).

Cultivation of cereal crop like maize under poplar trees could be ecologically viable option for soil fertility improvement and greater productivity of cereal crops and poplar trees for economic security of farmers adopting the system. However successful cultivation of cereal crops under agrisilviculture system requires information on species compatibility, arrangement of components and nutrient management practices. So far little work has been carried out to test the performance of maize crop with poplar and effect of integrated nutrient management on it under mid-hill sub humid conditions of Himachal Pradesh, which need further investigations. Therefore, in the present study emphasis will be given to test the effect of integrated nutrient management on the performance of maize crop in association with poplar.

\section{Materials and Methods}

The experiment was conducted at experimental farm of Department of Silviculture and Agroforestry, Dr Y S Parmar University of Horticulture and Forestry, Nauni, Solan (HP) in the year 2016. A structural component of experiment consist of three spacing viz., $S_{1}(6 \mathrm{~m} \times 4 \mathrm{~m}), S_{2}(4 \mathrm{~m} \times 4 \mathrm{~m})$ and $S_{3}$ (open control without trees) and six treatments viz., $\mathrm{T}_{1}(\mathrm{RDF}), \mathrm{T}_{2}(\mathrm{FYM}$ on $\mathrm{N}$ 
equivalent ratio), $\mathrm{T}_{3}$ ( $\mathrm{VC}$ on $\mathrm{N}$ equivalent ratio), $\mathrm{T}_{4}$ (75\% FYM and 25\% Vermicompost (on $\mathrm{N}$ equivalent ratio), $\mathrm{T}_{5}(50 \% \mathrm{FYM}$ and $50 \%$ Vermicompost (on $\mathrm{N}$ equivalent ratio) and $\mathrm{T}_{6} \quad(50 \% \quad(25 \% \mathrm{FYM}+25 \%$ Vermicompost $)+50 \%$ chemical fertilizer). The parameters determined were plant height, ear length, 1000 grain weight, grain yield, straw yield and harvest index. Crop growth parameters viz., plant height and ear length were recorded on the bases of ten plants randomly selected from each plant. Yield was calculated by recording weight of grains from each plot. The statistical design RBD factorial was used to analyse the data.

\section{Results and Discussion}

Data presented in the table 1 revealed that growth parameters viz., plant height and ear length were significantly influenced by different treatments and tree spacing. Plant height recorded maximum in the treatment $\mathrm{T} 6$ $(236.21 \mathrm{~cm})$ while, minimum was recorded in treatment T1 $(215.04 \mathrm{~cm})$. Among tree spacing, maximum plant height was reported in S3 $(248.67 \mathrm{~cm})$ and minimum was recorded under S2 (210.19). Plant height was maximum in open control area. This might be because of limited light availability for understory crops and light penetration is limited due to canopy interception. Hashim et al., (2015) also reported application of 50\% recommended dose of fertilizer (RDF) through chemical fertilizers and 50\% recommended dose of nitrogen (RDN) through crop residue mixed farmyard manure recorded the maximum growth attributes of maize.

The maximum cob length (Table 1) among treatments was recorded in $\mathrm{T}_{6}(14.67 \mathrm{~cm})$ while lowest was recorded in $\mathrm{T}_{1}(11.83 \mathrm{~cm})$. Maximum ear length of maize among tree spacing was recorded in $S_{3}(14.00 \mathrm{~cm})$ on the other hand minimum was recorded in $\mathrm{S}_{2}$
(12.74 cm). Gandhi and Dhiman (2010) also revealed that spikes were significantly smaller under denser tree spacings as compared less dense spacings. Hashim et al., (2015) reported application of $50 \%$ RDF through chemical fertilizers and 50\% recommended dose of nitrogen (RDN) through crop residue mixed farmyard manure recorded significantly higher cob length over control. Nanjappa et al., (2001) reported that combined application of 50 or $75 \%$ recommended dose of fertilizer with $12 \mathrm{t} \mathrm{ha}^{-1}$ FYM or $2.7 \mathrm{t} \mathrm{ha}^{-1}$ vermicompost caused higher productivity of maize compared with the application of either only inorganic fertilizer or organic sources.

Examination of the data presented in the Table 2 indicated that 1000 grain weight was influenced by fertilizer treatments and tree spacing. Highest grain weight was noticed in $\mathrm{T}_{6}(258.89 \mathrm{~g})$ while lowest was noticed in $\mathrm{T}_{1}$ (220.44 g).

Among tree spacing, $S_{3}$ recorded maximum grain weight $(244.61 \mathrm{~g})$ followed by $\mathrm{S}_{1}$ $(240.72 \mathrm{~g})$ and minimum grain weight was recorded in $\mathrm{S}_{2}(236.06 \mathrm{~g})$. However, interaction among fertilizer treatments and tree spacing showed no significant effect on grain weight. Grain mass depends on the date of sowing and harvest, quantity of nitrogen fertilizer, conditions for wheat growing, density of sowing, climate etc. 1000 grain weight of wheat and maize was influenced by poplar plantation. Nuberg and Mylins (2002) reported lower 1000-grain weight in sheltered crop (35.6 g) than in exposed crop (40.1 g) because of reduced photosynthetically active radiations.

Perusal of the table 2 depicts that grain yield was significantly influenced by fertilizer treatments, tree spacing and their interaction. Maximum grain yield was recorded in treatment $\mathrm{T}_{6}\left(23.26 \mathrm{q} \mathrm{ha}^{-1}\right)$ while minimum was recorded in $\mathrm{T}_{1}\left(13.49 \mathrm{q} \mathrm{ha}^{-1}\right)$. 
Int.J.Curr.Microbiol.App.Sci (2017) 6(8): 2692-2697

Table.1 Effect of INM and tree spacing on plant height $(\mathrm{cm})$ and cob length $(\mathrm{cm})$ of maize under Poplar based agroforestry system

\begin{tabular}{|c|c|c|c|c|c|c|c|c|}
\hline \multirow{2}{*}{$\begin{array}{c}\text { Spacing } \\
\text { Treatment }\end{array}$} & \multicolumn{4}{|c|}{ Plant height (cm) } & \multicolumn{4}{|c|}{ Cob length (cm) } \\
\hline & $\mathbf{S}_{1}$ & $\mathbf{S}_{2}$ & $\mathbf{S}_{3}$ & Mean & $\mathbf{S}_{1}$ & $\mathbf{S}_{2}$ & $\mathbf{S}_{3}$ & Mean \\
\hline$T_{1}$ & 208.97 & 200.10 & 236.07 & 215.04 & 11.63 & 11.33 & 12.53 & 11.83 \\
\hline $\mathbf{T}_{2}$ & 224.33 & 212.50 & 251.97 & 229.60 & 13.53 & 13.00 & 14.17 & 13.57 \\
\hline $\mathbf{T}_{3}$ & 227.93 & 217.23 & 256.60 & 233.92 & 14.47 & 13.20 & 14.83 & 14.17 \\
\hline $\mathbf{T}_{4}$ & 212.27 & 204.47 & 242.83 & 219.86 & 12.30 & 12.50 & 13.10 & 12.63 \\
\hline $\mathbf{T}_{5}$ & 219.77 & 207.27 & 244.33 & 223.79 & 13.07 & 12.80 & 13.70 & 13.19 \\
\hline$T_{6}$ & 228.83 & 219.60 & 260.20 & 236.21 & 14.70 & 13.63 & 15.67 & 14.67 \\
\hline & 220.35 & 210.19 & 248.67 & & 13.28 & 12.74 & 14.00 & \\
\hline $\mathrm{CD}_{0.05}$ & \multirow{4}{*}{\multicolumn{4}{|c|}{$\begin{array}{c}12.40 \\
8.77 \\
\mathrm{NS}\end{array}$}} & \multirow{4}{*}{\multicolumn{4}{|c|}{$\begin{array}{c}0.17 \\
0.12 \\
\text { NS }\end{array}$}} \\
\hline $\mathrm{T}$ & & & & & & & & \\
\hline $\bar{S}$ & & & & & & & & \\
\hline TXS & & & & & & & & \\
\hline
\end{tabular}

Table.2 Effect of INM and tree spacing on 1000 grain weight $(\mathrm{g})$ and grain yield $\left(\mathrm{q} \mathrm{ha}^{-1}\right)$ of maize under Poplar based agroforestry system

\begin{tabular}{|c|c|c|c|c|c|c|c|c|}
\hline \multirow{2}{*}{$\begin{array}{l}\text { Spacing } \\
\text { Treatment }\end{array}$} & \multicolumn{4}{|c|}{1000 grain weight $(\mathrm{g})$} & \multicolumn{4}{|c|}{ Grain yield $\left(\mathrm{q} \mathrm{ha}^{-1}\right)$} \\
\hline & $\mathbf{S}_{1}$ & $\mathbf{S}_{2}$ & $\mathbf{S}_{3}$ & Mean & $\mathbf{S}_{1}$ & $\mathbf{S}_{2}$ & $\mathbf{S}_{3}$ & Mean \\
\hline $\mathbf{T}_{1}$ & 220.00 & 216.33 & 225.00 & 220.44 & 10.50 & 10.50 & 19.47 & 13.49 \\
\hline $\mathbf{T}_{2}$ & 249.00 & 243.33 & 251.00 & 247.78 & 20.47 & 18.13 & 28.60 & 22.40 \\
\hline $\mathbf{T}_{3}$ & 253.00 & 247.67 & 255.33 & 252.00 & 19.70 & 17.53 & 27.67 & 21.63 \\
\hline $\mathbf{T}_{4}$ & 224.33 & 220.33 & 227.00 & 223.89 & 18.40 & 17.97 & 23.03 & 19.80 \\
\hline $\mathbf{T}_{5}$ & 240.00 & 237.33 & 242.00 & 239.78 & 18.80 & 17.00 & 25.33 & 20.38 \\
\hline$T_{6}$ & 258.00 & 251.33 & 267.33 & 258.89 & 21.83 & 18.43 & 29.50 & 23.26 \\
\hline & 240.72 & 236.06 & 244.61 & & 18.28 & 16.59 & 25.60 & \\
\hline $\mathrm{CD}_{0.05}$ & \multirow{4}{*}{\multicolumn{4}{|c|}{$\begin{array}{c}3.66 \\
2.59 \\
\text { NS }\end{array}$}} & \multirow{2}{*}{\multicolumn{4}{|c|}{0.26}} \\
\hline $\mathrm{T}$ & & & & & & & & \\
\hline $\bar{S}$ & & & & & \multicolumn{4}{|c|}{0.18} \\
\hline TX S & & & & & & & & \\
\hline
\end{tabular}

Table.3 Effect of INM and tree spacing on straw yield $\left(\mathrm{q} \mathrm{ha}^{-1}\right)$ and harvest index (\%) of maize under Poplar based agroforestry system

\begin{tabular}{|c|c|c|c|c|c|c|c|c|}
\hline \multirow{2}{*}{$\begin{array}{l}\text { Spacing } \\
\text { Treatment }\end{array}$} & \multicolumn{4}{|c|}{ Straw yield $\left(q\right.$ ha $\left.^{-1}\right)$} & \multicolumn{4}{|c|}{ Harvest index (\%) } \\
\hline & $S_{1}$ & $\mathbf{S}_{2}$ & $\mathbf{S}_{3}$ & Mean & $\mathbf{S}_{1}$ & $\mathbf{S}_{2}$ & $\mathbf{S}_{3}$ & Mean \\
\hline$T_{1}$ & 62.40 & 60.03 & 65.67 & 62.70 & 14.39 & 14.88 & 18.03 & 15.77 \\
\hline $\mathbf{T}_{2}$ & 69.00 & 67.53 & 72.97 & 69.83 & 26.88 & 26.62 & 26.84 & 26.78 \\
\hline $\mathbf{T}_{3}$ & 70.47 & 68.77 & 74.00 & 71.08 & 21.85 & 21.83 & 23.84 & 22.51 \\
\hline $\mathbf{T}_{4}$ & 64.67 & 62.10 & 68.60 & 65.12 & 22.15 & 22.44 & 23.01 & 22.53 \\
\hline$T_{5}$ & 66.73 & 62.90 & 70.40 & 66.68 & 21.98 & 22.73 & 23.28 & 22.66 \\
\hline \multirow[t]{2}{*}{$T_{6}$} & 72.77 & 71.65 & 75.67 & 73.36 & 26.47 & 51.01 & 27.32 & 34.93 \\
\hline & 67.67 & 65.50 & 71.22 & & 22.29 & 26.58 & 23.72 & 24.20 \\
\hline \multicolumn{9}{|l|}{$\mathrm{CD}_{0.05}$} \\
\hline $\mathrm{T}$ & & \multicolumn{4}{|c|}{7.56} \\
\hline $\mathrm{S}$ & \multicolumn{4}{|c|}{4.53} & \multicolumn{4}{|c|}{5.34} \\
\hline TX S & \multicolumn{4}{|c|}{ NS } & \multicolumn{4}{|c|}{ NS } \\
\hline
\end{tabular}


On the other hand, $\mathrm{S}_{3}$ reported maximum grain yield $\left(25.60 \mathrm{q} \mathrm{ha}^{-1}\right)$ and minimum grain yield (16.59 q ha-1) was reported in $S_{2}$. Mahesh et al., 2010 revealed that combined application of recommended dose of NPK $\left(150: 75: 40 \mathrm{~kg} \mathrm{ha}^{-1}\right)+$ FYM $10 \mathrm{t} \mathrm{ha}^{-1}$ recorded higher grain yield in maize. The results corroborate with the finding of Kumar et al., 2013 and Das et al., (2017). Newaj et al., (2003) showed that the grain yield of pure crop was higher than that from the tree crop systems in Albizia procera based agroforestry system.

Table 3 revealed that significantly highest straw yield among fertilizer treatments was recorded in $\mathrm{T}_{6}\left(73.36 \mathrm{q} \mathrm{ha}^{-1}\right)$ while lowest was recorded in $\mathrm{T}_{1}\left(62.70 \mathrm{q} \mathrm{ha}^{-1}\right)$ which was statistically at par with $\mathrm{T}_{4}\left(65.12 \mathrm{q} \mathrm{ha}^{-1}\right)$ and $\mathrm{T}_{5}\left(66.68 \mathrm{q} \mathrm{ha}^{-1}\right)$. Straw yield among tree spacing was reported significantly higher in $\mathrm{T}_{3}\left(71.22 \mathrm{q} \mathrm{ha}^{-1}\right)$ on the other hand minimum was reported in $\mathrm{S}_{2}\left(65.50 \mathrm{ha}^{-1}\right)$. Straw yield of crop is basically a product of number of tillers, plant height and dry matter accumulation which affect the straw yield significantly. It was lower under poplar plantations as compared to open. This difference was due to above and below ground competition hence shades of trees and root development of trees adversely affect the yield of associated crops. Straw yield was significant among spacings and was maximum in $S_{3}$ followed by $S_{1}$ and $S_{2}$. Kumar et al., (2006) also observed lower straw productivity under narrow tree spacing as compared to broader spacing. Likewise, Kakraliya et al., 2017 reported that integration of chemical fertilizers with organic manures increased straw yield significantly over chemical fertilizers alone.

Harvest index was found to be significant in relation to fertilizer treatments and tree spacing. Maximum harvest index was reported in $\mathrm{T}_{6}(34.93 \%)$ and minimum was reported in $\mathrm{T}_{1}(15.77 \%)$. Among tree spacing highest harvest index was noted in $\mathrm{S}_{2}$ $(26.58 \%)$ and minimum was under $S_{1}$ (22.29).The results are in confirmation with Chaudhary et al., (2016) who reported that the combination of FYM, chemical fertilizers and inoculation had pronounced effect on soil fertility that resulted in better vegetative growth in plant height, no. of branch plant ${ }^{-1}$, seeds pod $^{-1}$, pods plant ${ }^{-1}$, stover yield, grain yields, biological yield and harvest index.

In conclusion, integrated nutrient management and tree spacing influenced the growth parameters of Zea mays in terms of plant height, cob length, 1000 grain weight, grain yield and straw yield. Growth parameters were found higher in $\mathrm{S}_{3}$ (without trees) and lowest in $\mathrm{S}_{2}(4 \mathrm{~m} X 4 \mathrm{~m})$. Combined use of organic manures with inorganic fertilizers improved the growth parameters of Zea mays. Treatment $\mathrm{T}_{6}$ was more effective in improving production potential of Zea mays. From this investigation it can be concluded that maize crop perform better in integration of organic and inorganic fertilizers as compare to sole organic and inorganic fertilizers. Further being a $\mathrm{C}_{4}$ plant it flourish better in open conditions as compare to under trees. Its adoption in agroforestry requires various canopy management practices to reduce light competition.

\section{References}

Albiach. R., Canet, R., Pomares, F. and Ingelmo, F. 2000. Microbial biomass content and enzymatic activities after the application of organic amendments to a horticultural soil. Bioresource Technology.75: 43-48

Chandra, J. P. 1986. Poplar - A cash crop for north Indian farmers. Indian Forester. 112: 698-710

Chauhan, S. K. and Mangat, P. S. 2006. Poplar based agroforestry is ideal for 
Punjab, India. Asia-Pacific Agroforestry News. 28: 7-8

Chaudhary, M., Singh, S., Babu, S. and Prasad, M. 2016. Effect of integrated nutrient management on yield and yield attributes of blackgram (Phaseolus mungo L.) in an inceptisol of Varanasi. International Journal of Applied and Pure Science and Agriculture. 2(6): 235-238.

Das, R. C., Somanagouda, G. and Singh, B. 2017. Effect of integrated nutrient management practices on growth, yield and oil yield of safflower (Carthamus tinctoriusL.). International Journal of Current Microbiology and Applied Sciences, 6(4): 511-516

Gandhi, J. N. and Dhiman, R. C. 2010. Performance of wheat intercropped under different tree spacings of poplar (Populus deltoides Marsh.) plantations. Indian Journal of Agroforestry.12:28-31

GIEWS-Global Information and Early Warning

System.http://www.fao.org/giews/count rybrief/country.jsp?code $=$ IND.2016

Hashim, M., Dhar, S., Vyas, A. K., Pramesh, V. and Kumar, B. 2015. Integrated nutrient management in maize (Zea mays)-wheat (Triticum aestivum) cropping system. Indian Journal of Agronomy.60 (3): 352-359

Kakraliya, S. K., Jat, R. D., Kumar, S., Choudhary, K. K., Prakash, J. and Singh, L. K. 2017. Integrated nutrient management for improving fertilizer use efficiency, soil biodiversity and productivity of wheat in irrigated rice wheat cropping system in IndoGangatic plains of India. International Journal of Current Microbiology and
Applied Sciences.6 (3): 152-163

Kumar, K., Nandal, D. P. S. and Dahiya, D. 2006. Effect of fertilizer levels on yield and nutrient uptake of wheat intersown with poplar. Indian Journal of Forestr.29 (1): 55-61

Kumar, R., Sood, S., Kasana, R. C., Pathania, V. L., Singh, B. and Singh, R. D. 2013. Effect of plant spacing and organic mulch on growth, yield and quality of natural sweetener plant Stevia and soil fertility in western Himalayas. International Journal of Plant Production.8 (3): 1735-1741

Nanjappa, H. V., Ramachandrappa, B. K. and Mallikarjun, B. O. 2001. Effect of integrated nutrient management on yield and nutrient balance in maize (Zea mays). Indian Journal of Agronomy.46 (4): 698-701

Newaj, M. K. R., Bhargava, R. S., Yadav, A. and Shankar, A. K. 2003. Tree-crop interaction in Albizia procera based agroforestry system in relation to soil moisture, light and nutrients. Indian Journal of Agroforestry.5 (1\&2): 17-19

Nuberg, I. K. and Mylins, S. J. 2002. Effect of shelter on the yield and water use of wheat. Australian Journal of Experimental Agriculture.42: 773-780

Sharma, K. K. 1996. Agroforestry in farming systems development. Indian Forester.122 (7): 547-559

Singh, B. and Sharma, K. N. 2006. Tree growth and nutrient status of soil in a poplar based agroforestry system in Punjab, India. Agroforestry Systems.70: $125-134$

\section{How to cite this article:}

Garima and Pant, K.S. 2017. Effect of Integrated Nutrient Management and Tree Spacing on Production Potential of Maize (Zea mays) Under Poplar Based Agroforestry System. Int.J.Curr.Microbiol.App.Sci. 6(8): 2692-2697. doi: https://doi.org/10.20546/ijcmas.2017.608.322 